\title{
Sessile serrated adenoma invading a diverticulum in the right colon: tips and tricks for a safe complete endoscopic resection
}

Large sessile serrated adenomas are at high risk of incomplete resection because of difficulty visualizing their margins [1]. Moreover, cases involving invasion of a diverticulum are technically challenging and carry a high risk of perforation. Here, we report on a $3.5-\mathrm{cm}$ sessile serrated adenoma in the right colon with invasion of the diverticulum ( $>$ Fig. 1 a, $>$ Video 1 ).

To identify the margin, acid acetic spraying [2] was combined with blue-laser imaging virtual chromoendoscopy to produce a clear whitish area with excellent contrast between the lesion and normal mucosae ( $\mathbf{F i g} \mathbf{1} \mathbf{b}$ ). Then, endoscopic submucosal dissection was performed using our double-clip traction (DCT) technique [3,4] ( Fig.2a). After injecting the margin far from the diverticulum with a glycerol mixture, a circumferential incision was made. Countertraction using the DCT technique enabled us to identify a good submucosal dissection plane, even in the diverticulum area. After rapid en bloc resection of the $3.5-\mathrm{cm}$ sessile serrated adenoma, we decided to close the area because of the high risk of delayed perforation secondary to diverticulum involvement. Small incisions were made in the mucosa

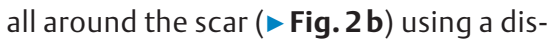
section knife, which enabled hemoclips to grasp the tissue and facilitated closure of the large scar within 2 minutes ( $\triangleright$ Fig. $2 \mathrm{c}$ ).

Pathological analysis revealed a nondysplastic sessile serrated adenoma, and the patient was discharged on the day of the procedure.

Many simple, inexpensive techniques have been described for the removal of
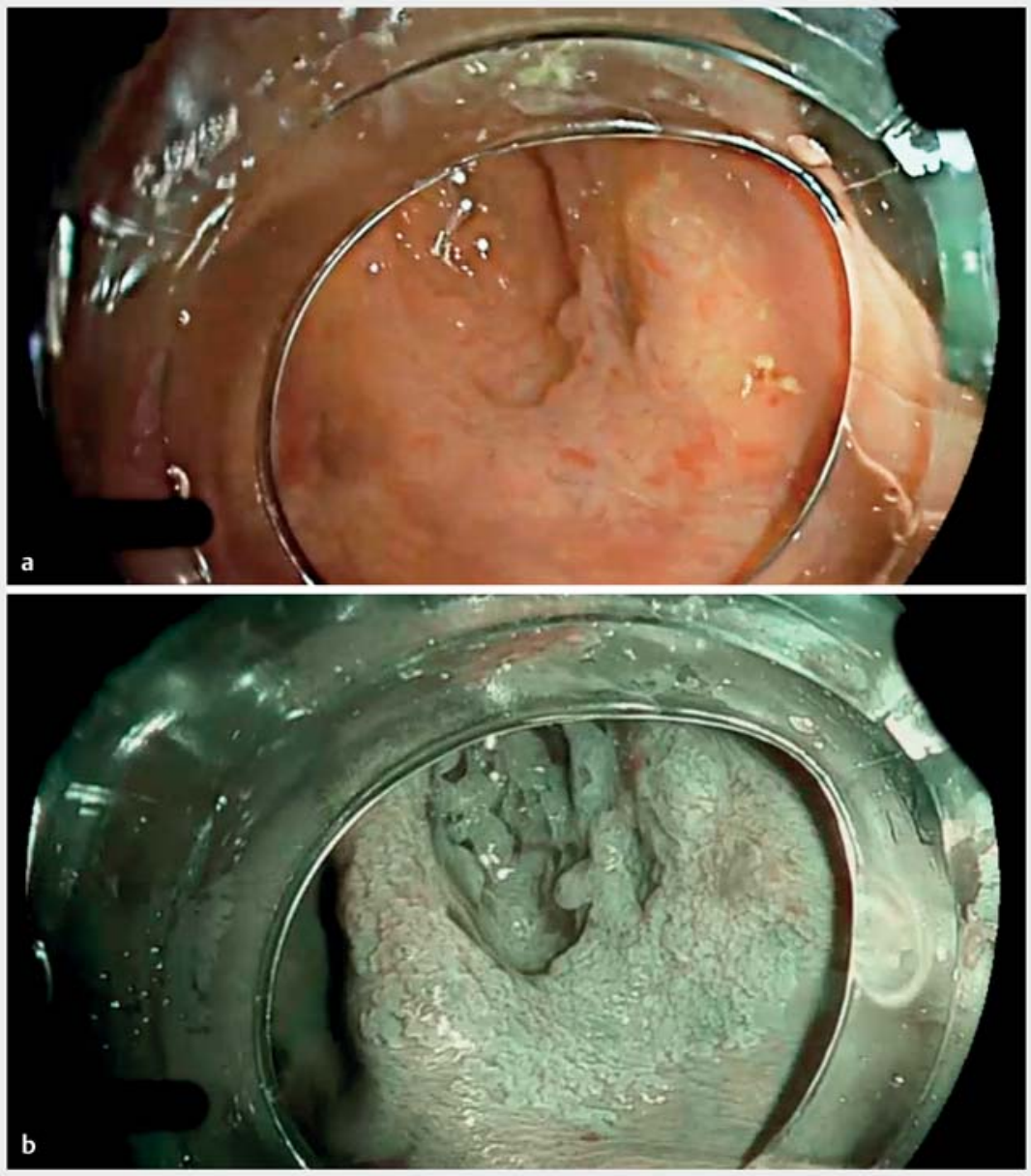

- Fig. 1 Sessile serrated adenoma invading a diverticulum. a No clear margins were visible. b Clear margins after acetic acid spraying.

lesions that, until recently, were considered too difficult for an endoscopic approach. Physicians should be aware of these techniques.

Endoscopy_UCTN_Code_TTT_1AQ_2AD

\section{Competing interests}

J. Jacques, R. Legros and M. Pioche are consultants for Olympus. 

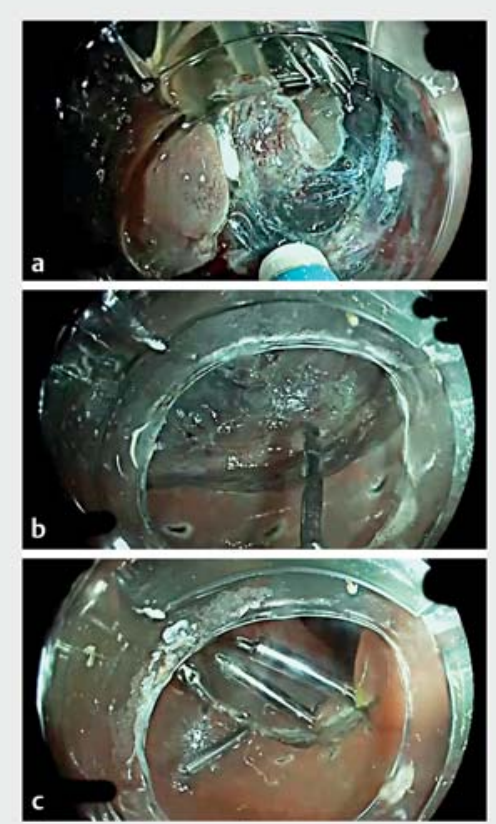

- Fig. 2 Endoscopic submucosal dissection of the lesion. a The double-clip traction technique was used. b Small incisions were made in the normal mucosa to help clip closure of the scar. c Closure of the scar.

The authors

Sophie Geyl ${ }^{1}$, Jérémie Albouys ${ }^{1}$, Romain Legros $^{1}$, Hugo Lepetit ${ }^{1}$, Martin Dahan ${ }^{1}$, Mathieu Pioche ${ }^{2}$, Jérémie Jacques ${ }^{1}$

1 Service d'Hépato-gastro-entérologie, $\mathrm{CHU}$ Dupuytren, Limoges, France

2 Service d'Hépato-gastro-entérologie, Hôpital Édouard Herriot, Lyon, France

\section{Corresponding author}

\section{Jérémie Jacques, MD}

Service d'Hépato-gastro-entérologie, $\mathrm{CHU}$

Dupuytren, 2 avenue Martin-Luther-King,

87042, Limoges, France

jeremiejacques@gmail.com
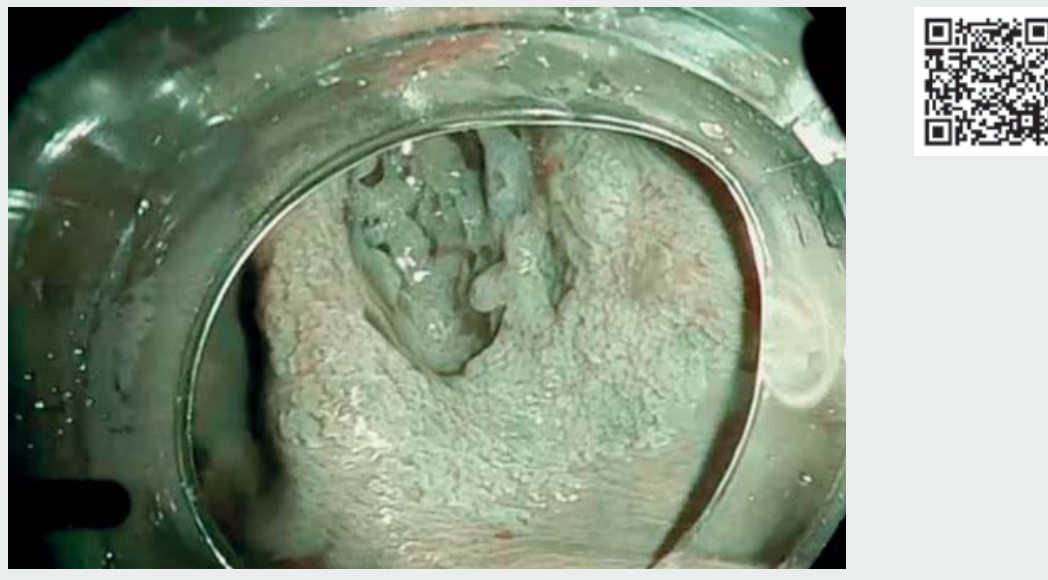

Video 1 Sessile serrated adenoma invading a diverticulum in the right colon: tips and tricks for a safe complete endoscopic resection.

\section{References}

[1] Pohl H, Srivastava A, Bensen SP et al. Incomplete polyp resection during colonoscopy - results of the Complete Adenoma Resection (CARE) study. Gastroenterology 2013; 144: 74-80

[2] Onishi K, Kono Y, Higashi R. Acetic acid spray with narrow-band imaging is useful to clarify the margin of sessile serrated adenoma/ polyp. Am J Gastroenterol 2020; 115: 1160

[3] Jacques ], Charissoux A, Bordillon P et al. High proficiency of colonic endoscopic submucosal dissection in Europe thanks to countertraction strategy using a double clip and rubber band. Endosc Int Open 2019; 7: E1166-E1174

[4] Jacques ], Charissoux A, Legros R et al. Double-clip counter-traction using a rubber band is a useful and adaptive tool for colonic endoscopic submucosal dissection. Endoscopy 2018; 50: 179-181

\section{Bibliography}

Endoscopy 2022; 54: E170-E171

DOI 10.1055/a-1463-2045

ISSN 0013-726X

published online 28.4.2021

(c) 2021. Thieme. All rights reserved.

Georg Thieme Verlag KG, Rüdigerstraße 14,

70469 Stuttgart, Germany

\section{ENDOSCOPY E-VIDEOS}

https://eref.thieme.de/e-videos

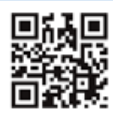

Endoscopy E-Videos is an open access online section, reporting on interesting cases and new techniques in gastroenterological endoscopy. All papers include a high quality video and all contributions are freely accessible online. Processing charges apply (currently EUR 375), discounts and wavers acc. to HINARI are available.

This section has its own submission website at https://mc.manuscriptcentral.com/e-videos 